\title{
NILAI-NILAI ISLAM DALAM UPACARA ADAT PERNIKAHAN SUNDA
}

\author{
Ilfa Harfiatul Haq \\ UIN Sunan Gunung Djati Bandung \\ J1. A.H. Nasution 105 Cibiru Kota Bandung \\ Email: ilfa.harfiatulhaq@ymail.com
}

\begin{abstract}
Pernikahan adalah sebuah ikatan yang memadukan dua insan yaitu laki-laki dan perempuan atas dasar cinta dan tentunya atas ijin-Nya. Pernikahan diwujudkan dengan harapan hanya sekali dalam seumur hidup, sehingga dianggap sebagai ritual yang sakral. Penulis pun tertarik melalukan penelitian dengan tema pernikahan adat yang berbudaya dengan sisi agamisnya. Adapun tujuan dalam penelitian ini adalah untuk mengungkap inti permasalahan yaitu nilainilai Islam yang terkandung dalam upacara adat pernikahan Sunda. Penelitian ini dilakukan dengan menggunakan metode dan pendekatan studi Islam. Pernikahan dilaksanakan secara Islam dengan perpaduan kebudayaan daerah setempat, khususnya di daerah Sunda. Pernikahan adat Sunda diselenggarakan dengan beberapa susunan acara yang menjadi tradisi dan ciri khas budaya sunda, tetapi terkandung nilai-nilai Islam di dalamnya karena telah melalui proses Islamisasi. Nilai-nilai Islam itu telah diresapi tanpa meninggalkan nilai-nilai adat setempat yang tidak bertentangan dengan Syari'at Islam.
\end{abstract}

Keywords: Islam, Tradisi, Pernikahan

Abstract

Marriage is a bond that combines two people namely men and women on the basis of love and of course with his permission. Marriage is realized with hope only once in a lifetime, so it is considered a sacred ritual. The author is interested in doing research with the theme of traditional marriage that is cultured with its religious side. The purpose of this study is to uncover the essence of the problem, namely Islamic values contained in the Sundanese wedding ceremony. This research was conducted using methods and approaches to Islamic studies. Marriage is carried out in Islam with a blend of local culture, especially in the Sunda region. Sundanese custom marriages are held with several events which become traditions and characteristics of Sundanese culture, but contain Islamic values in it because they have gone through the process of Islamization. Islamic values have been infused without abandoning local custom values that do not conflict with Shari'at Islam

Keywords: Islam, Tradition, marriage

\section{A. PENDAHULUAN}

Agama Islam dianut oleh sebagian besar masyarakat Sunda dan sedikit sekali masyarakat Sunda yang memeluk agama lain seperti Katolik, Protestan, Hindu, Buddha, dan sebagainya. Masyarakat Sunda kebanyakan taat menjalankan ajaran agama Islam, seperti menjalankan sholat lima waktu, sholat jum'at, puasa, membayar 
zakat, dan memiliki keinginan yang sangat besar untuk dapat menunaikan ibadah haji ke tanah suci. Menurut pandangan masyarakat Sunda, agama itu harus menjadi ageman yang artinya harus menjadi pegangan atau pedoman hidup dalam bermasyarakat untuk bekal di kehidupan akhirat kelak. ${ }^{1}$

Pendidikan agama Islam umumnya diperoleh sejak anak-anak sekitar usia 7 tahun, kebanyakan memulai belajar mengaji atas arahan guru ngaji di surau. Tidak hanya di surau, madrasah-madrasah pun menjadi sarana menuntut ilmu agama yang dipelajari dari seorang guru agama. Apabila anak-anak telah tamat mengaji seluruh ayat al-Qur'an, maka diadakan hataman; dan untuk kenaikan kelas di madrasah-madrasah selalu diadakan imtihan. Pendidikan agama bagi orang-orang tua dilakukan dengan diadakannya pengajian rutin, ada yang seminggu sekali, dua kali atau tiga kali. ${ }^{2}$ Bahkan saat ini semakin banyak diadakan pengajian umum di berbagai tempat karena mengingat kondisi zaman yang semakin berubah, maka dirasa perlu adanya pengokohan akidah.

Penerangan agama melalui ceramah yang disampaikan oleh seorang kiai atau ulama senantiasa dilakukan bersamaan

A. Suhandi Suhamihardja, Agama, Kepercayaan, dan Sistem Pengetahuan, dalam Edi S. Ekadjati (Ed.), Masyarakat Sunda dan Kebudayaannya, (Jakarta: PT Girimukti Pasaka, 1984), hlm. 279-280. dengan peringatan hari-hari besar Islam, seperti kelahiran Nabi Muhammad SAW diperingati setiap bulan Maulud; dan Isra Mi'raj Nabi Muhammad SAW yang diperingati di setiap bulan Rajab. ${ }^{3}$ Tidak hanya itu, saat menjelang bulan Ramadhan pun senantiasa dilakukan Tabligh Akbar; dan saat setelah berlangsungnya Idul Fitri pun senantiasa diadakan acara halal bi halal dengan mengundang seorang ulama untuk berceramah sesuai dengan temanya.

Kehidupan keagamaan dalam masyarakat Sunda juga tampak di dalam upacara-upacara selamatan yang berhubungan dengan tahap-tahap lingkaran hidup seseorang dari mulai kelahiran, khitanan, dan pernikahan. Upacara selamatan yang sering dilaksanakan merupakan perwujudan rasa syukur kepada Tuhan Yang Maha Esa atas segala karuniaNya. ${ }^{4}$ Rasa syukur diwujudkan dalam upacara selamatan dan itu merupakan tradisi masyarakat pra-Islam, Prinsip dasar masyarakat Sunda senantiasa dilandasi oleh tiga sifat utama yakni silih asah, silih asih, dan silih asuh atau bisa diartikan sebagai saling mengajari, saling menyayangi, dan saling menjaga. Ketiga sifat itu selalu tampak dalam berbagai upacara adat Sunda, terutama pada upacara adat pernikahan,

\footnotetext{
${ }^{2}$ A. Suhandi Suhamihardja, Ibid., hlm. 280.

${ }^{3}$ Ibid., hlm. 280-281.

${ }^{4}$ Ibid., hlm. 281.
} 
karena pasangan yang menikah harus saling menyayangi, menjaga dan mengingatkan satu sama lain dalam kebaikan.

Upacara pernikahan adat Sunda terbagi ke dalam tiga bagian: sebelum akad nikah (preluminal), akad nikah (luminal) dan sesudah akad nikah (postluminal). Masing-masing bagian tersebut memiliki simbol dan makna. Pernikahan adat Sunda ini secara langsung ataupun tidak, telah menyerap nilai-nilai agama Islam yang datang pada abad ke-15 di Tanah Sunda. Hal ini yang menjadikan nilai-nilai dan norma adat Sunda yang terpaparkan memang telah mengalami Islamisasi. Islamisasi ini pun terus berlanjut, tanpa menghilangkan nilai adat Sunda yang tidak bertentangan dengan nilai agama Islam. ${ }^{5}$ Berangkat dari realita tersebut, penulis menyadari akan adanya nilai-nilai Islam yang terkandung dalam serangkaian prosesi upacara adat pernikahan Sunda.

\section{B. KONSEP PERNIKAHAN DALAM ISLAM}

Nikah merupakan salah satu asas pokok hidup yang paling utama dalam kehidupan manusia. Pernikahan itu bukan saja merupakan satu jalan yang amat mulia untuk mengatur kehidupan rumah tangga dan keturunan, tetapi juga dapat dipandang

${ }^{5}$ Mu'min Maulana, 2013, "Upacara Daur Hidup dalam Pernikahan Adat Sunda”, Refleksi, 13 (5), hlm. 623. sebagai satu jalan menuju pintu perkenalan antara suatu kaum dengan kaum lain, dan perkenalan itu akan menjadi jalan untuk menyambungkan ikatan pertalian antara yang satu dengan yang lainnya. ${ }^{6}$

Pertalian nikah adalah pertalian yang seteguh-teguhnya dalam hidup dan kehidupan manusia, bukan saja antara suami istri dan keturunannya, melainkan juga antara dua keluarga. Semua keluarga dari kedua belah pihak akan terjalin sebuah hubungan keluarga, maka dari situ akan semakin memperkuat sikap saling peduli dan tolong menolong dalam segala urusan. ${ }^{7}$ Pernikahan tentunya akan mendatangkan banyak kebaikan bagi kedua belah pihak dan keturunan berikutnya.

Suatu pernikahan sangat berguna dalam memelihara kerukunan anak cucu (keturunan), sebab kalau tidak dengan nikah, tentulah anak akan tidak berketentuan terkait siapa yang akan mengurusnya dan siapa yang bertanggung jawab atasnya. Nikah juga dipandang sebagai kemaslahatan umum, sebab kalau tidak ada pernikahan, tentu manusia akan menurutkan sifat kebinatangan, dan dengan sikap itu akan timbul perselisihan, bencana, dan permusuhan antar sesamanya, yang dimungkinkan juga sampai menimbulkan

\footnotetext{
${ }^{6}$ Sulaiman Rasjid, Fiqh Islam, (Bandung: Sinar Baru Algesindo, 2011), hlm. 374.

${ }^{7}$ Sulaiman Rasjid, Ibid.
} 
pembunuhan yang maha dahsyat. $^{8}$ Pernikahan dalam Islam sejatinya untuk kemaslahatan dalam berumah tangga dan berketurunan, juga untuk kemaslahatan masyarakat secara umum.

Islam memandang bahwa pernikahan merupakan sesuatu yang luhur dan sakral, bermakna ibadah kepada Allah SWT, mengikuti Sunnah Rasulullah dan dilaksanakan atas dasar keikhlasan, tanggungjawab, dan mengikuti ketentuanketentuan hukum yang harus diindahkan. Dalam Undang-Undang RI Nomor 1 tahun 1974 tentang Perkawinan Bab I pasal 1, perkawinan ialah ikatan lahir bathin antara seorang laki-laki dengan seorang perempuan sebagai pasangan suami-isteri dengan tujuan membentuk keluarga (rumah tangga) yang bahagia dan abadi berdasarkan Ketuhanan Yang Maha Esa. ${ }^{9}$ Pada intinya pernikahan adalah suatu ikatan lahir bathin antara seorang laki-laki dan perempuan untuk hidup bersama dalam suatu rumah tangga dan untuk berketurunan, yang dilaksanakan menurut ketentuan syari'at Islam.

Pernikahan merupakan sunnah Nabi Muhammad SAW, sunnah dalam pengertian mencontoh tindak laku beliau. ${ }^{10}$ Pernikahan dilaksanakan supaya manusia mempunyai

\footnotetext{
${ }^{8}$ Sulaiman Rasjid, Ibid., hlm. 375.

9 Mulati, Hukum Perkawinan Islam, (Tanggerang: Pustaka Mandiri, 2012), hlm. 1.

10 Nadimah Tandjung, Islam dan Perkawinan, (Djakarta: Penerbit Bulan Bintang, 1965), hlm. 19.
}

keturunan dan hidup rukun bersama keluarga di bawah naungan cinta kasih dan ridha Allah SWT. Sebagaimana Allah SWT befirman dalam QS. Ar-Rum ayat 21 dan QS. An-Nahl ayat 72, yaitu sebagai berikut: "Dan di antara tanda-tanda (kebesaran)-Nya ialah Dia menciptakan pasangan-pasangan untukmu dari jenismu sendiri, agar kamu cenderung dan merasa tenteram kepadanya, dan Dia menjadikan di antaramu rasa kasih dan sayang. Sungguh, pada yang demikian itu benar-benar terdapat tanda-tanda (kebesaran Allah) bagi kaum yang berpikir." (QS. Ar-Rum: 21); dan "Allah menjadikan bagi kamu isteri-isteri dari jenis kamu sendiri dan menjadikan bagimu dari isteri-isteri kamu itu, anak-anak dan cucu-cucu, dan memberimu rezeki dari yang baik-baik. Maka mengapakah mereka beriman kepada yang bathil dan mengingkari nikmat Allah" (QS. An-Nahl: 72). ${ }^{11}$

Hukum asal dari nikah adalah boleh, tetapi bisa berubah menjadi wajib, sunnah, makruh atau haram, hal ini tergantung dari niat dan keadaan pelaku (calon mempelai). Dalam hukum Islam, pernikahan yang sah adalah yang memenuhi rukun dan syaratsyarat pernikahan. Jika rukun dan syarat terpenuhi, maka pernikahan dianggap sah.

\footnotetext{
${ }^{11}$ Nadimah Tandjung, Ibid., hlm. 21.
} 
Adapun rukun pernikahan meliputi: calon pengantin pria, calon pengantin perempuan, wali nikah, dua orang saksi, akad (ijab qabul), mahar. Sedangkan syaratsyarat pernikahan adalah sebagai berikut:

1. Untuk calon pengantin pria, harus beragama Islam, jelas orangnya, tidak terkena halangan pernikahan, tidak sedang melaksanakan haji atau umroh, belum mempunyai empat orang isteri;

2. Untuk calon pengantin perempuan, beragama Islam, jelas orangnya, tidak terkena halangan pernikahan, tidak dalam masa iddah (bagi janda), tidak sedang melaksanakan haji atau umroh, dan dapat dimintai persetujuan;

3. Untuk wali, harus beragama Islam, lakilaki, adil, mempunyai hak atas perwalian, tidak terkena halangan untuk menjadi wali, dan tidak sedang melaksanakan haji atau umroh. ${ }^{12}$

Jika rukunnya tidak lengkap dan syarat-syaratnya tidak terpenuhi maka akan menimbulkan ketidakwenangan untuk melakukan pernikahan atau akan berakibat pada batalnya pernikahan.

\section{RANGKAIAN PROSESI UPACARA ADAT PERNIKAHAN SUNDA}

Pernikahan merupakan suatu tahap baru dalam perjalanan hidup manusia saat

\footnotetext{
12 Sa'diyah, NH. 2011. Perkawinan dalam Islam. Dalam http://etheses.uin-malang.ac.id. Diakses tanggal 8 Oktober 2018.
}

dirinya menginjak usia dewasa. ${ }^{13}$ Pernikahan adalah momentum yang sakral dan dinantikan oleh setiap pasangan. Istilah sakral bagi masyarakat Sunda yaitu sebagai sarana manusia berhubungan dengan Ilahi. Hal ini menjadikan kebanyakan pasangan melakukan persiapan pernikahan jauh hari sebelumnya, dan yang paling penting dilakukan oleh pasangan dalam menjelang pernikahan adalah mendekatkan diri kepada Allah dan memohon restu-Nya agar penikahan yang akan dilangsungkan dapat berjalan dengan lancar dan sesuai harapan.

Menurut masyarakat Sunda, dalam suatu ikatan pernikahan dengan dipersatukannya laki-laki dan perempuan maka akan menjadi satu jiwa. Hal itu merupakan filosofi pernikahan bagi masyarakat sunda, sehingga perceraian sangat dihindari dan tidak boleh samapai dilakukan atau bahkan haram hukumnya, kecuali atas kehendak Allah dan salah satunya meninggal dunia. Pernikahan dianggap sakral dengan harapan hanya sekali dalam seumur hidup.

Dalam setiap kehidupan suatu masyarakat senantiasa akan tercipta normanorma, seperti: secara, kebiasaan, tata kelakuan, dan adat istiadat. Dalam prosesi pernikahan adat sunda, terdapat beberapa

13 Edi S Ekadjati, Kebudayaan Sunda (Suatu Pendekatan Sejarah), (Jakarta: Pustaka Jaya, 1995), hlm. 86. 
ritual yang perlu dipahami maknanya bersama, karena dalam pernikahan yang ada di Indonesia khususnya adat Sunda, memiliki arti yang sakral, baik penghormatan kepada Tuhan maupun kepada orang tua. Pernikahan adat Sunda sangat kental dengan penghormatan kaum perempuan dan suasana yang penuh dengan kebahagiaan. Berikut ini adalah rangkaian upacara adat pernikahan sunda, yaitu di antaranya:

\section{Pelaksanaan Sebelum Upacara Pernikahan}

\section{a. Upacara Neundeun Omong}

Upacara neundeun omong merupakan langkah awal dalam proses perkawinan Sunda. Neundeun omong mempunyai arti "titip pesan" atau "mengadakan perjanjian". Upacara dilaksanakan setelah adanya saling mengenal antara calon pengantin pria dan calon pengantin wanita. Dalam proses pelaksanaannya, biasanya orang tua jejaka datang berkunjung kepada orang tua gadis idamannya. Hal ini bisa dilakukan sendiri atau bisa mengutus orang lain yang dipercaya. Jumlah orang yang datang biasanya hanya dua atau tiga orang saja. Begitu pula orang yang menerimanya cukup orang tua gadis yang didatangi. Pelaksanaannya sederhana, biasanya tetangga pun kadang-kadang tidak tahu. Dalam upacara neundeun omong ini, sifatnya tidak mengikat, karena dari kedua belah pihak belum sampai pada penetapan dan menjanjikan sesuatu, hanya sekadar rencana yang masih perlu dipertimbangkan lebih lanjut. Mungkin saja suatu saat salah satu pihak membatalkan karena alasan tertentu. Selama kurun neundeun omong, kedua belah pihak saling mengawasi gerak gerik, keadaan tingkah laku kedua anaknya, selain itu mereka pun biasanya saling bersilaturahmi. Situasi dan pergaulan antara si jejaka dengan si gadis sangat terbatas, bagi mereka dianggap sebagai ujian pertama. Kedua belah pihak berusaha untuk tidak sampai terjadi sesuatu yang tidak menyenangkan, karena dalam kurun waktu neundeun omong ini, orang tua dari kedua belah pihak sudah mulai memikirkan tentang rencana pernikahan nanti.

\section{b. Upacara Ngalamar}

Ngalamar merupakan langkah kedua yang biasa dilaksanakan dalam adat perkawinan Sunda. Ngalamar ini biasanya dilaksanakan setelah upacara neundeun omong yang jangka waktunya beberapa bulan saja. Biasanya pihak laki-laki memiliki peran penting untuk menentukan pelaksanaanya. Walaupun pada prinsipnya kesepakatan kedua belah pihak sangat diutamakan, karena akan menyangkut soal biaya dan bahkan untuk melangsungkan perkawinan nanti. Dalam adat perkawinan orang Sunda, upacara ngalamar maknanya sama dengan 
kata nanyaan (meminang). Dalam acara ngalamar ini, orang tua si jejaka atau utusannya bertanya tentang keberadaan gadis impian anaknya, apakah masih bebas dan tidak terikat oleh lelaki lain. Seandainya masih bebas, apakah rela atau tidak untuk dipersunting anaknya. Umumnya pada acara lamaran, bukan orang tua si jejaka, tetapi yang menyampaikan maksud tersebut, biasanya mengutus orang lain, walaupun keduanya sama-sama datang. Sebelum pelaksanaan upacara ngalamar, jauh-jauh hari pihak lelaki, biasanya sudah memberi tahu kepada pihak orang tua wanita tentang acara lamaran ini. Hal ini dilakukan untuk memberi waktu melakukan persiapan di pihak orang tua wanita. Dalam upacara pinangan atau ngalamar ini diperoleh beberapa hal: Pertama orang tua, baik orang tua calon pengantin laki-laki maupun orang yang mewakili. Orang yang mewakili biasanya mengerti tentang tata cara adat istiadat dan memiliki kepandaian dalam berbicara. Kedua, orang-orang yang hadir. Dalam hal ini, orang-orang tersebut hanya sebagai tanda penguat atau saksi bilamana lamaran diterima. Ketiga adalah barang bawaan.

\section{c. Upacara Nyangcang}

Tunangan dalam bahasa sunda biasanya disebut papacangan. Dalam masa tunangan ini, pergaulan antara si calon pengantin lakilaki dan calon pengantin wanita agak diperlonggar, tetapi masih tetap dalam pengawasan orang tua dan tidak bebas. Hubungan mereka dijaga jangan sampai melanggar norma-norma susila, baik norma agama maupun norma yang berhubungan dengan adat istiadat. Dalam masa tunangan ini, walaupun kedua belah pihak sudah sama-sama mengikat janji, tidak menutup kemungkinan pertunangan atau perjanjian diputuskan karena salah satu pihak melakukan pelanggaran atau kesan yang kurang baik, baik putus secara sepihak maupun atas kesepakatan kedua belah pihak. Lamanya pertunangan tidak ditentukan, tetapi umumnya hanya beberapa bulan saja, lebih-lebih karena menurut adat orang tua yang mengatakan "pamali lila-lila papacangan", artinya terlarang untuk lamalama bertunangan. Dalam merencanakan ke jenjang pernikahan berdasarkan hasil kesepakatan antara kedua belah pihak, biasanya bergantung pada kesempatan dan persediaan biaya. Dalam pelaksanaannya yang harus memikirkan secara sunguhsungguh adalah pihak orang tua wanita, sebab pelaksanaan perkawinan dilangsungkan di kediaman calon pengantin wanita dan menjadi tanggungan pihak wanita. Bahkan bila dilaksanakan hajatan secara besar-besaran akan memerlukan biaya besar, walaupun biasanya pihak calon pengantin laki-laki membantu. 


\section{d. Upacara Narikan}

Narikan merupakan adat yang isinya membicarakan kepastian pelaksanaan perkawinan, baik hari, tanggal, maupun waktunya. Untuk mendapatkan hari, tanggal dan waktu tersebut, biasanya menggunakan perhitungan yang berdasarkan kepercayaan masyarakat setempat. Hal itu bertujuan agar rumah tangga bahagia, menurut pandangan mereka. Berdasarkan perhitungan ini biasanya disepakati oleh kedua belah pihak. Perhitungan yang dipakai mulai hari, tanggal, waktu (jam), sampai waktu pagi dan siangnya. Bulan yang dijadikan pedoman menggunakan bulan Islam, dan yang banyak dipakai biasanya bulan Zulhijjah. Bulan tersebut dalam bahasa Sunda disebut bulan Rayagung merupakan bulan besar dan mulia. Upacara narikan ini biasanya berakhir dengan kesepakatan kedua belah pihak. Kesepakatan ini menyangkut berbagai hal tentang perkawinan, bahkan sampai pada masalah siapa orang-orang yang harus diundang, jika sudah pada masalah terakhir tadi barulah kesepakatan dianggap sempurna. Masalah biaya biasanya tidak dirundingkan dalam upacara narikan ini, karena masalah biaya hanya ditanggung oleh pihak wanita.

\section{e. Upacara Seserahan}

Upacara adat seserahan bermakna penyerahan atau menyerahkan, dalam upacara ini seserahan artinya menyerahkan atau memasrahkan calon pengantin laki-laki kepada calon orang tua dari calon pengantin perempuan, untuk kemudian dinikahkan kepada calon pengantin perempuan. Pada saat yang telah ditentukan terlebih dahulu serta telah diperbincangkan dengan orang tua mempelai perempuan, maka berangkatlah rombongan orang tua mempelai laki-laki. Apabila rumah mereka berdekatan, perjalanan dilakukan dengan berjalan kaki. Akan tetapi kalau jaraknya jauh, perjalanan dilakukan dengan menggunakan kendaraan, dan beberapa meter lagi menuju rumah mempelai perempuan rombongan turun. Waktu berjalan calon mempelai laki-laki berada di muka berdampingan dengan orang tuanya. Sementara itu di belakang mereka iringan keluarga serta handai taulan yang membawa serta barang-barang (bingkisan) untuk mempelai pengantin perempuan. Makin banyak orang yang ikut serta dalam rombongan makin besar hati kedua belah pihak. Tentang banyak serta nilai dari barang-barang yang dibawa bergantung pada kemampuan pihak mempelai laki- laki. Setibanya di rumah calon besan, rombongan mempelai laki- laki dielu-elukan dengan gembira dan dipersilakan duduk secara terhormat oleh tuan rumah sekeluarga serta 
para tamu undangan. Iringan tamu duduk berhadap- hadapan dengan pihak tuan rumah serta tamu lainnya. Barang bingkisan disimpan di tengah-tengah di hadapan hadirin. Setelah keadaan telah tenang, tidak menunggu lama biasanya pihak tamu memulai angkat bicara, baik orang tua mempelai pengantin laki-laki itu sendiri maupun perwakilannya. Seandainya dalam seserahan itu orang tua mempelai pengantin laki-laki mewakilkan kepada orang lain, maka wakil itu memohon maaf atas kedatangan yang mungkin menyusahkan tuan rumah. Ia pun mengucapkan terima kasih atas penerimaan yang sangat mengesankan, kemudian ia mengucapkan kata penyerahannya. Setelah kata sambutan dari pihak tamu, sekarang bagian pihak tuan rumah yang memberikan kata sambutan. Sambutan bisa langsung oleh orang tua dari mempelai perempuan atau juga bisa diwakilkan. Sambutan tersebut ditutup dengan do'a keselamatan.

\section{f. Upacara Ngeuyeuk Seureuh}

Kata ngeuyeuk asal katanya heuyeuk. Kata tersebut mempunyai dua pengertian, yaitu sama dengan mengatur, mengurus, atau mengerjakan. Misalnya: ngaheuyeuk nagara artinya mengurus negara, ngeuyeuk pare yang artinya mengerjakan padi supaya butirnya lepas. Adapun ngeuyeuk seureuh artinya mengerjakan dan mengatur sirih serta mengait-ngaitkannya. Waktu untuk melakukan upacara ngeuyeuk seureuh adalah di petang hari, sehari sebelum hari penikahan. Dalam pelaksanaannya, dipimpin oleh seorang wanita yang telah berumur yang ahli dalam bidang upacara tersebut. Ia dibantu oleh seorang laki-laki yang telah berumur juga, yang bertugas membacakan do'a. Dalam pelaksanaannya, mereka duduk beralaskan tikar, tidak disediakan kursi, termasuk untuk kedua calon pengantin yang harus ikut hadir. Tempat yang dipergunakan untuk upacara ini biasanya dipergunakan tengah rumah yang cukup luas. Setelah berbagai keperluan dan pelaksanaan siap, yang akan memimpin upacara (ketua) membuka acara. Mula-mula ketua meminta permohonan maaf mengenai pelaksanaan upacara. Dalam uraiannya beliau menyampaikan mengenai tugas yang diembannya, bahwa tugas tersebut merupakan permintaan dari orang tua calon mempelai wanita. Kepada semua yang hadir diminta bantuan untuk mengikuti acara ini dengan penuh khidmat agar terhindar dari hal-hal yang dapat mengganggu jalannya upacara. Serta mengajak pula berdoa kepada Allah SWT agar kedua mempelai mendapat rahmat, serta dapat membangun rumah tangga yang sakinah, mawadah, warohmah.

\section{Pelaksanaan Upacara Pernikahan}


Upacara akad nikah atau walimah adalah upacara adat perkawinan yang pokok, baik secara adat maupun secara agama Islam. Sebab satu dan lain hal upacara-upacara lain terpaksa diabaikan (tidak dijalankan), maka upacara akad nikah ini sekali-kali tidak boleh tidak, harus dijalankan. Kalau upacara ini tidak dilaksanakan berarti perkawinannya dianggap tidak sah. Orang bisa dikawinkan hanya bilamana telah memenuhi ketentuan-ketentuan yang telah digariskan dan bersendikan agama Islam serta adat. Tempat untuk melangsungkan walimah adalah di masjid yang di antaranya memang sudah disediakan untuk itu. Akan tetapi untuk yang menginginkan di rumah sendiri pun bisa. Pada saat yang telah ditentukan terlebih dahulu dan biasanya di pagi hari, kedua mempelai berangkat bersama-sama menuju masjid. Mereka diantar oleh wali, orang-orang tua dan keluarga kedua belah pihak. Tiba di masjid, kedua mempelai duduk bersanding diapit oleh orang tua mereka. Mereka duduk berhadap-hadapan dengan penghulu dan di kanan-kirinya didampingi dua orang saksi. Keluarga dan pengantar lainnya duduk berkeliling. Mereka dikawinkan oleh orang tua perempuan melalui "penghulu" mereka. Setelah proses akad nikah selesai, mereka menuju rumah. Setiba di rumah, mereka disambut dengan meriah oleh seisi rumah beserta keluarga kedua belah pihak, juga para tamu yang meluangkan waktu datang pada saat itu untuk bersalam-salaman dan mendapat do'a serta ucapan selamat.

\section{Upacara Sesudah Perkawinan a. Upacara Sawer (nyawer)}

Sawer atau nyawer asal katanya awer, mempunyai arti air jatuh menciprat, sesuai dengan praktek juru sawer yang menaburnaburkan perlengkapan nyawer, seolah-olah menciprat-cipratkan air kepada kedua mempelai wanita dan pria serta semua yang ikut menyaksikan di sekelilingnya. Akan tetapi besar pula kemungkinannya bahwa perilaku adat ini disebut nyawer oleh karena dilaksanakan di panyaweran atau taeuran, yang dalam bahasa Indonesia disebut cucuran atap. Adapaun perlengkapan untuk nyawer terdiri atas beras putih, irisan kunir tipis, uang kecil (receh), yang jumlahnya menurut keinginan, dan biasanya uang logam agar mudah dilemparkan.

\section{b. Upacara Nincak Endog}

Selesai upacara nyawer kedua mempelai wanita dan pria dibimbing maju mendekati rumah tangga. Mempelai pria menginjak telur dengan kaki kanannya hingga pecah. Kemudian langsung dicuci oleh mempelai wanita dengan air kendi yang telah tersedia. Kendi dipecahkan sehabis dipakai menyatakan kepuasan hati. Kedua mempelai terus bergandengan naik ke rumah 
mendekati pintu. Sampai di muka pintu mempelai wanita masuk ke dalam rumah, sementara mempelai pria ditinggal di luar. Makna dari proses tersebut, bahwa walaupun akad nikah dan upacara lain sudah dilaksanakan, ia masih harus menjalani ujian tentang kebenarannya beragama Islam. Setelah mempelai wanita mengucapkan syahadat, maka pintu pun dibuka, sang pria disambut oleh isterinya dengan sembah sungkem dan berjalan menuju ke tempat huap lingkung.

\section{c. Upacara Huap Lingkung}

Huap lingkung terdiri atas dua kata yaitu huap yang berarti suap, dan lingkung, akar kata Indonesia melingkungi, mengurung. Perlengkapan yang disiapkan dalam upacara ini pada pokoknya nasi kuning, bekakak ayam ialah panggang yang bagian dadanya dibelah dua, dan air minum. Kedua mempelai bersanding, yang wanita di sebelah kiri pria. Mula-mula keduanya disuruh memegang bekakak ayam yang hanya satu itu, masing- masing di sisi kanan dan kirinya. Mereka saling menarik bekakak ayam tersebut hingga terbelah menjadi dua. Siapa yang mendapat bagian terbesar di tangannya, disebutkan ialah yang akan paling banyak memperoleh rejeki di antara keduanya. Hal itu juga mengandung makna bahwa bagi orang yang bersuami isteri

${ }^{14}$ Enden Irma Rachmawaty, 2011, "Makna dan Simbol dalam Upacara Adat Perkawinan Sunda di Kabupaten Bandung”, Patanjala, 3 (2), hlm. 247-258. memberi tidak terbatas, dengan tulus dan ikhlas sepenuh hati. Sehabis upacara huap lingkung, kedua mempelai dipersilakan berdiri di pelaminan diapit oleh kedua orang tua masing-masing untuk menerima para tamu. ${ }^{14}$

Simbol dan makna yang terdapat dalam rangkaian kegiatan upacara adat pernikahan tersebut memiliki nilai yang masih dianggap cukup tinggi oleh masyarakat Sunda pada umumnya. Hal itu tampak dari sebagian masyarakat yang masih melaksanakan upacara adat pernikahan ini dengan segala syarat yang diharuskan dalam pelaksanaan kegiatan upacara tersebut, yaitu mulai dari kegiatan pranikah sampai pasca nikah. Simbolsimbol hanya diartikan sebagai simbol yang bernuansa budaya yang terkadang hanya dijadikan sarana kemeriahan pesta upacara adat pernikahan. ${ }^{15}$

Upacara pernikahan adat Sunda di Jawa Barat terdapat hal-hal yang masih tetap dipertahankan hingga saat ini, namun ada pula yang sudah mulai tidak dipergunakan atau dikurangi intensitasnya. Hal ini dikarenakan adanya penyesuaian dengan ajaran Islam, kondisi jaman, lingkungan tempat, dan kemampuan pemangku hajat.

\footnotetext{
${ }^{15}$ Enden Irma Rachmawaty, Ibid., hlm. 258-259.
} 


\section{NILAI-NILAI ISLAM YANG TERKANDUNG DALAM UPACARA ADAT PERNIKAHAN SUNDA}

Ketika agama Islam masuk ke Indonesia pada sekitaran abad yang jauh sebelumnya, saat itu kondisi masyarakat Indonesia telah tertata dengan sistem nilai yang berlaku berupa peraturan-peraturan adat masyarakat setempat. Hukum adat yang berlaku dalam masyarakat Indonesia kemudian bertemu dengan nilai-nilai Islam berupa akidah dan syari'ah. Sesuai dengan hakikat dakwah Islam, nilai-nilai Islam itu telah diresapi tanpa meninggalkan nilai-nilai adat setempat yang tidak bertentangan dengan Syari’at Islam.

Asimilasi dan Akulturasi antar dua kebudayaan, dalam hal ini kebudayaan Sunda dengan kebudayaan Islam, maka akan melahirkan suatu bentuk kebudayaan baru yang merupakan hasil titik temu dari proses pembauran terus-menerus antara berbagai kebudayaan yang berbeda tersebut. Titik temu antara nilai-nilai Sunda dengan nilai-nilai Islam adalah lebih kepada etika atau tatakrama. Sistem muamalah yang diajarkan Islam menemukan realitas empirisnya dalam kehidupan masyarakat Sunda. Apa yang dicita-citakan oleh masyarakat Sunda tentang cageur bageur, someah ka semah, nyaah ka sasama sesuai

16 Dadang Kahmad, 2008, Agama Islam dan Budaya Sunda, dalam http://dkahmad.blogspot.com, diakses tanggal 8 Oktober 2018. dengan ajaran Islam. ${ }^{16}$ Kehadiran Islam di tanah Sunda memberikan solusi terhadap keinginan masyarakat Sunda untuk menjalani hidup lebih baik.

Pengaruh agama Islam pada kehidupan orang-orang Sunda dapat dilihat dari beberapa hukum adat yang mereka laksanakan dalam bermasyarakat. Dalam pernikahan pun dilaksanakan secara fiqh Islam yang dipadukan dengan upacara adat, seperti: ngeuyeuk seureuh, buka pintu, sawer, dan huaplingkung. Upacara adat yang berhubungan dengan proses kehidupan manusia termasuk pernikahan merupakan upacara adat yang dipadukan dengan do'ado'a dari ajaran Islam. Dalam kesempatan itu, para pemimpin agama yang bijaksana biasanya memberitahukan kepada hadirin, bahwa upacara adat tersebut bukan merupakan suatu kewajiban yang harus dilakukan olah orang Islam. $^{17}$ Adat pernikahan di suatu daerah itu bisa dipertahankan dan dilestarikan apabila adat tersebut tidak menyalahi ajaran Islam.

Upacara adat pernikahan Sunda mempunyai kandungan nilai-nilai yang bersifat religius dengan tujuan pelaksanaannya untuk memohon keselamatan dan keberkahan kepada Allah SWT. Kandungan nilai religius terdapat di setiap tahapan dari rangkaian prosesi

\footnotetext{
${ }^{17}$ Dadang Kahmad, Ibid.
} 
pernikahan adat Sunda yang mempunyai makna yaitu jika ingin mengharapkan sesuatu maka harus disertai dengan usaha yang sungguh-sungguh dan senantiasa mendekatkan diri kepada Allah SWT.

Pernikahan adat Sunda memiliki aturan pernikahan yang selaras dengan ajaran agama Islam. Ketika menikah, kedua mempelai menjalaninya sesuai dengan syariat yang diajarkan dengan melengkapi rukun dan syarat dalam pernikahan yaitu adanya mempelai laki-laki dan perempuan, wali yang melangsungkan akad dengan suami dan dua orang saksi yang menyaksikan telah berlangsungnya akad pernikahan. Setelah semua syarat dan rukun terpenuhi, maka acara pernikahan juga melibatkan pemerintah, yaitu Pegawai Pencatat Nikah yang bertugas untuk mencatatkan pernikahan mereka agar sah menurut hukum negara dan sesuai dengan Kompilasi Hukum Islam pasal 5. ${ }^{18}$

Islamisasi yang terjadi di masyarakat Indonesia, khususnya masyarakat Sunda, di masyarakat pedesaan secara umum terkait dengan afiliasi sosial dan kultural para anggota masyarakat. Ketika masyarakat pedesaan menyelanggarakan ritus-ritus sosial keagamaan tersebut, secara langsung maupun tidak langsung mereka akan

18 Lutfiyah, 2014, "Relasi Budaya dan Agama dalam Pernikahan”, Jurnal Hukum Islam (JHI), 12 (1), hlm. 4.

${ }^{19}$ Lutfiyah, Ibid., hlm. 6. memasuki sebuah sistem sosial-keagamaan. Durkheim berpendapat bahwa agama adalah sarana kohesi sosial. Ciri keberagamaan tersebut tidak lepas dari ritus-ritus yang melibatkan partispasi masyarakat secara massal. Agama tidak hanya dimaknai sebagai penghayatan pribadi terhadap Tuhan, melainkan sebuah ritus bersama untuk mencapai keselarasan. Durkheim menyebut bahwa "yang sacral" dalam masyarakat adalah yang menyangkut eksistensi kedaerahan. ${ }^{19}$

Kebudayaan dan agama, masingmasingnya mempunyai simbol-simbol dan nilai tersendiri. Agama adalah simbol yang melambangkan nilai ketaatan kepada Tuhan. Kebudayaan juga mengandung nilai dan simbol supaya manusia bisa hidup di dalamnya. Agama memerlukan sistem simbol, dengan kata lain agama memerlukan kebudayaan agama. Tetapi keduanya perlu dibedakan, agama sebagai sesuatu yang final, universal, abadi (parennial) dan tidak mengenal perubahan (absolut), sedangkan kebudayaan bersifat partikular, relatif dan temporer. Agama tanpa kebudayaan memang dapat berkembang sebagai agama pribadi, tetapi tanpa kebudayaan agama sebagai kolektivitas tidak akan mendapat tempat. ${ }^{20}$ Agama dalam hal ini Islam telah

20 Kuntowijoyo, dalam Ahmad Ripa'i, 2012, "Dialektika Islam dan Budaya Sunda", Holistik, 13 (2), hlm. 50. 
memberikan warna pada kebudayaaan, sedangkan kebudayaan memberi kekayaan terhadap agama.

\section{E. KESIMPULAN}

Berdasarkan penelusuran dari yang telah disampaikan sebelumnya, dengan mengkaji berbagai sumber yang bersangkutan untuk menjawab semua permasalah, maka penulis dapat menarik kesimpulan sebagai berikut:

1. Pernikahan dalam pandangan Islam merupakan sesuatu yang luhur dan sakral, bermakna ibadah kepada Allah SWT, mengikuti Sunnah Rasulullah dan dilaksanakan atas dasar keikhlasan, tanggungjawab, dan mengikuti ketentuan-ketentuan hukum, rukun dan syarat-syarat yang harus diperhatikan. Bila hukumnya ada bertentangan, rukunnya tidak lengkap dan syaratsyaratnya tidak terpenuhi maka akan menimbulkan ketidakwenangan untuk melakukan pernikahan atau akan berakibat pada batalnya pernikahan.

2. Upacara pernikahan adat Sunda terbagi ke dalam tiga bagian: sebelum akad nikah, saat akad nikah, dan setelah akad nikah. Rangkaian prosesi upacara adat sebelum berlangsungnya akad nikah, di antaranya: Neundeun Omong (Mengikat), Narosan (Melamar), Seserahan, Ngencangkeun aisan (Lepasnya tanggungjawab kedua orang tua calon pengantin), Siraman, Ngeuyeuk seureuh (Permohonan restu kepada orang tua mempelai dan pemberian nasihat dari kedua orang tua mempelai); kemudian rangkaian prosesi saat berlangsungnya akad, yaitu di antaranya: penjemputan calon pengantin pria, penyerahan calon pengantin pria, akad nikah, penyerahan mas kawin dan simbolis, dan sungkeman; Setelah itu memasuki rangkaian upacara adat setelah berlangsungnya akad, yaitu di antaranya: saweran, nincak endok (menginjak telur), meuleum harupat (membakar lidi), buka pintu, huap lingkung (saling menyuapi), dan melepaskan burung merpati. Masingmasing bagian tersebut memiliki simbol dan makna. Simbol-simbol hanya diartikan sebagai simbol yang bernuansa budaya yang terkadang hanya dijadikan sarana kemeriahan pesta upacara adat pernikahan.

3. Pernikahan di Sunda dilaksanakan secara fiqh Islam yang dipadukan dengan upacara adat, seperti: ngeuyeuk seureuh, buka pintu, sawer, dan huap lingkung. Upacara adat pernikahan pun mempunyai kandungan nilai-nilai Islam yang bertujuan untuk memohon keselamatan dan berkah kepada Allah SWT. Kandungan nilai Islam terdapat di setiap tahapan dari rangkaian prosesi pernikahan adat Sunda yang mempunyai 
makna yaitu jika ingin mengharapkan sesuatu harus disertai dengan usaha yang sungguh-sungguh dan senantiasa mendekatkan diri kepada Allah SWT. Upacara adat yang berhubungan dengan proses kehidupan manusia termasuk pernikahan merupakan upacara adat yang dipadukan dengan do'a-do'a dari ajaran Islam. Upacara adat bagi umat Islam bukan merupakan suatu keharusan, tetapi lebih kepada keinginan dari sebagian pihak untuk melaksanakannya. Kebudayaan dan agama, masingmasingnya mempunyai simbol-simbol dan nilai tersendiri. Agama adalah simbol yang melambangkan nilai ketaatan kepada Tuhan, sementara kebudayaan juga mengandung nilai dan simbol supaya manusia bisa hidup di dalamnya.

\section{F. REFERENSI}

1. Buku

Ekadjati, Edi S. 1995. Kebudayaan Sunda (Suatu Pendekatan Sejarah). Jakarta: Pustaka Jaya.

1984. Masyarakat Sunda dan Kebudayaannya. Jakarta: PT Girimukti Pasaka.

Mulati. 2012. Hukum Perkawinan Islam. Tanggerang: Pustaka Mandiri.

Rasjid, Sulaiman. Fiqh Islam. 2011. Bandung: Sinar Baru Algesindo.

Tandjung, Nadimah. 1965. Islam dan Perkawinan. Djakarta: Penerbit Bulan Bintang.

\section{Jurnal}

Lutfiyah. 2014. "Relasi Budaya dan Agama dalam Pernikahan". Jurnal Hukum Islam (JHI). 12 (1).

Maulana, Mu'min. 2013. “Upacara Daur Hidup dalam Pernikahan Adat Sunda". Refleksi. 13 (5).

Rachmawaty, E Irma. 2011. "Makna dan Simbol dalam Upacara Adat Perkawinan Sunda di Kabupaten Bandung”. Patanjala. 3 (2).

Ripa'i, Ahmad. 2012. "Dialektika Islam dan Budaya Sunda". Holistik. 13 (2).

\section{Artikel dalam Internet}

Kahmad, Dadang. 2008. Agama Islam dan Budaya Sunda. Dalam http://dkahmad.blogspot.com.

Diakses tanggal 10 Oktober 2018.

Sa'diyah, NH. 2011. Perkawinan dalam Islam. Dalam http://etheses.uinmalang.ac.id. Diakses tanggal 8 Oktober 2018. 